\title{
TRANSLATION OF CLASSICS OF GERMAN POETRY IN UKRAINIAN
}

\section{ПЕРЕКЛАД КЛАСИКІВ НІМЕЦЬКОЇ ПОЕЗІЇ УКРАЇНСЬКОЮ МОВОЮ}

\section{Petro Osipov ${ }^{1}$ \\ Nataliia Bulyk ${ }^{2}$}

DOI: https://doi.org/10.30525/978-9934-26-069-8-9

\begin{abstract}
Translation issues have long been in the field of view of translators and philologists-researchers. The focus was on the definition of the translation process in view of its psychological and lexical-semantic features and its perception as a certain creative action. The translation process is always functionally and thematically defined and controlled. Its main purpose is to provide the necessary information and establish communication between people of different languages and cultures. Considering translation as an interlingual communication process, we address the question of what language operations should be performed to ensure the integration of source and target texts and at the same time eliminate their interlinguistic structural differences at the conceptual and stylistic levels. The dominant of any translation is its goal (skopos), because differences in the definition of translation goals cause, in turn, differences in interlingual translation strategies. The translator's understanding of the text presupposes his knowledge of the history of society, institutions, social conditions, religious beliefs, culturally and situationally determined patterns of speech activity and behavior of the «source culture», as well as knowledge of the syntax and semantics of the «source text» and their structures. Each translation creates a dynamic connection and is an intercultural transfer of the text insofar as it takes into account the culturally specific comparison of language, situation and object in question. From the standpoint of hermeneutics and from the
\end{abstract}

\footnotetext{
${ }^{1}$ Candidate of Philological Sciences, Associate Professor, Professor of the German Philology and Translation Department, V.O. Sukhomlynskyi Mykolaiv National University, Ukraine ${ }^{2}$ Teacher of the German Philology and Translation Department, V.O. Sukhomlynskyi Mykolaiv National University, Ukraine
} 
point of view of translation, the difference of cultures means the difference between "source culture» and thus - the culture of "source language» and «target culture» and thus - the culture of «target language». The analysis focuses on the translation of the most famous poems of German classics. In J. Goethe, along with the ballad «Erlkönig» («The Forest King»), it is his popular excerpts from the tragedy «Faust». The translation was made by famous writers B. Hrinchenko and M. Rylsky. F. Schiller's poetry is represented by his ballads «Pirnach» («DerTaucher») and «Glove» («DerHandschuh»). The latter was translated by the famous poet and translator M. Orest. Heine's works were translated into Ukrainian by such well-known writers as I. Franko, L. Pervomaisky and others.

\section{1. Ветуп}

Вихідним положенням визначення процесу перекладу з огляду на його психологічні та лексико-семантичні особливості може слугувати сприйняття перекладу як певної творчої дії, що спрямована як на вихідний текст (ВТ) - текст, з якого перекладають, так і на текст призначення (ПТ) - текст, на який перекладають; процес перекладу є завжди функціонально й тематично окресленим і контрольованим; він відбувається свідомо, планомірно, реалізуючи своє головне призначення: забезпечення необхідною інформацією і встановлення комунікації між представниками різних мов і культур. Переклад сприймається також як процес трансформування мовленнєвої продукції з однієї мови в іншу за умови збереження ії змісту й значення, передбачаючи, таким чином, відповідність між одиницями ВТ й створеним на його базі ПТ, інакше - між одиницями різних мов.

Говорячи про переклад творів німецьких авторів, привертає до себе увагу той факт, що саме на теренах німецької філософії і теорії перекладу з'явилися певні пролегомени зародження перекладу як науки. Досить згадати, принаймні декілька особливостей, якими закладено підгрунтя до цього. Визначальною у цьому контексті була насамперед гіпотеза Вільгельма фон Гумбольдта (W. Humboldt) [13] про єдність мови і мислення, яку вчений розглядав у зв'язку з рідною мовою. Мова, на думку класика, є проявом духу народу (Geist der Sprache). Він додає, що жодне слово однієї мови не відповідає абсолютно його аналогу в іншій мові. 
Схожу думку висловлював також сучасник Гумбольдта - Ф. Шляєрмахер (F. Schleiermacher), який в роботі «Über die verschiedenen Methoden des Übersetzens» [2] («Про різні методи перекладу») звертав увагу на необхідність збереження духу вихідної мови. Дослідженнями семантики займався Л. Вайсгербер (Leo Weisgerber), який в роботі «Inhaltbezogene Grammatik» («Граматика, що спирається на зміст») вказував, що кожна мова становить відносно закриту систему, що надзвичайно ускладнює процес перекладу.

Особливе місце в становленні перекладу як науки займає принцип лінгвістичного релятивізму - «linguistische Relativitätsprinzip» (гіпотеза Сепіра-Уорфа). Пошук нових теорій перекладу, переведення їх у практичну площину триває і до сьогодні.

\section{2. Теоретичні розвідки проблем перекладу}

Аналіз останніх публікацій з теорії та практики перекладу [5; 6; 7; $8 ; 10 ; 11]$ свідчить про постійно зростаючу увагу вчених щодо термінів «еквівалент / еквівалентний», «адекватність / адекватний», проте важко навести ще, принаймні, одне поняття сфери наукового перекладу, у визначенні якого існує стільки розбіжностей. Безперечним сприймається твердження, що при еквівалентності понять йдеться про відношення (Relation) між ВТ і ПТ, проте природа і ступінь цих відношень залишаються чітко не визначеними. Еквівалентність перекладу ототожнюється інколи 3 адекватністю, часом вона слугує синонімом перекладу або замінюється поняттями наближення чи апроксимації (Annäherung, approximation). При цьому мовна (текстова) еквівалентність передбачає також ії культурну відповідність.

Розглядаючи переклад як міжмовний процес комунікації, ми торкаємося питання, які мовні операції слід виконати, щоб забезпечити інтеграцію вихідного та цільового текстів і разом з тим усунути їх інтерлінгвістичні структурні відмінності на понятійному та стилістичному рівнях [12, с. 62]. Домінантою будь-якого перекладу виступає його ціль (skopos), оскільки відмінності у визначенні цілей перекладу зумовлюють, у свою чергу, розбіжності щодо можливих стратегій перекладу.

Схожість (або несхожість) перекладу детермінована комунікативною ситуацією, в якій знаходиться перекладач. Про адекватність 
перекладу можна говорити лише в міру того, яку конкретну уяву перекладач має про ситуацію перекладу ї як він спроможний ідентифікувати себе як мовно діючу особу через цю свідомість. Однією 3 передумов досягнення адекватності перекладу мусить бути холістичний підхід до тексту, тобто поняття цілісності тексту як по відношенню до оригіналу, так I до перекладу. Цілісність означає при цьому певний когерентний утвір, окремі конституенти якого підпорядковані значенню цілого. Це стосується як безпосередньо лексико-семантичних одиниць тексту, так і тлумачення окремих лінгвокраїнознавчих понять і реалій, що виражають певні культурно-специфічні відносини і зв'язки.

Практика міжкультурної комунікації свідчить, що знання лексико-граматичної системи іноземної мови ще не гарантує досягнення взаємного порозуміння у процесі перекладу, оскільки розбіжності у функціонуванні мов та їх культурна зумовленість можуть привести до непорозуміння і ускладнюють комунікацію.

Метою роботи є стислий вибірковий аналіз перекладу українською мовою окремих поезій класиків німецької літератури кінця XVIII ст. першої половини XIX ст. - Й. Гете, Ф. Шиллер, Г. Гейне, а також їх порівняння із іншими відомими доробками. Вирізняючись своєю самобутністю й неповторністю стилю, ці неперевершені майстри Слова у своїй творчості не полишали взаємних пошуків передати гуманістичні ідеї та виразність образів, які допомагають людині усвідомити своє місце в суспільстві. Людині, яка стикається з вадами своєї епохи, із залишками феодальної системи, а також із світоглядно-моральним падінням бюргерського класу.

\section{3. Особливості перекладу творів Й. В. Гете}

Безперечним лідером у зазначеній когорті вважається, без сумніву, Й. В. Гете. Ми зосередили нашу увагу, насамперед, на феномені та проблемі Слова. Звертаючись до етимологічного витоку терміна «слово», констатуємо, що семантичний узус грец. «logos», від якого воно походить, був від початку значно ширшим. Цю багатозначність «logos» глибоко й дотепно висвітлює Гете, коли варіанту «Слово» М. Лютера протиставляє (як можливі) варіанти смислу (Sinn) та сили (Kraft), зупиняючись остаточно на варіанті «діло» (Tat). 
Geschrieben steht: "Im Anfang war das Wort!»

Hier stock ich schon! Wer hilft mir weiter fort?

Ich kann das Wort so hoch unmöglich schätzen,

Ich muss es anders übersetzen,

Wenn ich vom Geiste recht erleuchtet bin.

Geschrieben steht: Im Anfang war der Sinn.

Bedenke wohl die erste Zeile,

Daß deine Feder sich nicht übereile!

Ist es der Sinn, der alles wirkt und schafft?

Es sollte stehn: Im Anfang war die Kraft!

Doch, auch indem ich dieses niederschreibe,

Schon warnt mich was, daß ich dabei nicht bleibe.

Mir hilft der Geist! Auf einmal seh ich Rat

Und schreibe getrost: Im Anfang war die Tat! [3, c. 912]

Ось тут написано: “Спочатку було Слово!»

Стривай, постій! - Ця думка помилкова;

Не можу Слову на́дмір я покласти, -

Інакше мушу перекласти;

Ось перли розсуду сіяють променисті,

Там надпис є: «Спочатку були Мислі».

Все ж треба знову добре міркувати,

Не слід перу надмірно поспішати!

Якщзо то мисль наразі все створила, -

Писати б мусили: «Спочатку була Сила!»

А втім, хай навіть цее сумлінно напишу,

Де впевненість, що знов не погрішу?

Та розум - радник мій! Я бачу вихід смілий

I, втішений, пишу: «Спочатку було Діло!»

Невичерпне за своєю красою і глибиною творіння поета-мислителя, «Фауст», містить у собі не готову істину, а наочний варіант іiі дослідження. Боротьбі добра і зла, сил розуму й відвертого цинізму досягають свого апогею у другій частині твору (акт 5, сцена перед палацом), де, за трагічною іронією долі, Фауст, пригнічений сліпотою й відчуттям власного кінця, дістається, попри все, твердих переконань щодо смислу життя, який полягає у самовідданому служінню наро- 
ду, прагненні до свободи і справедливості. Його заключний монолог стосується майбутнього, він слугує своєрідним пророкуванням і проектом, до якого варто прагнути і який є вищим покликанням усього життя. Яскравою ілюстраціє цього є рядки твору:

Ja! Diesem Sinne bin ich ganz ergeben,

Das ist der Weißheit letzter Schluß:

Nur der verdient sich Freiheit wie das Leben,

Der täglich sie erobern muß.

Und so verbringt, umrungen von Gefahr,

Hier Kindheit, Mann und Greis sein tüchtig Jahr.

Solch ein Gewimmel möchte ich sehn, Auf freiem Grund mit freiem Volke stehn.

Zum Augenblick dürft ich sagen:

Verweile doch, du bist so schön.

Es kann die Spur von meinen Erdetagen

Nicht in Äonen untergehn, -

Im Vorgefühl von solchem hohen Glück

Genieß ich jetzt den schönsten Augenblick. [13, c. 505-506]

«Так! Вищого покликання не знаю,

Ось мудрість вся щуоденного буття:

Лиш той, хто кривду повсякчас долає,

Достойний і свободи і життя.

В полоні зла час неухильно плине,

Йому підвладні стареизь і дитина;

Побачити б я залюбки хотів

Народ мій вільний і щзасливість днів;

Щоб міг сказати (сам бо шзасний):

«O, мить, спинися, - ти прекрасна!»

Не можуть дні життя земного

Без сліду в вічність одійти. -

Таким передчуттям моя душа бринить,

Найвищу нині відчуваю мить.

Цими словами вже котрий раз у своїй творчості Гете стверджує домінуючий початок дії, творчості й відстоює примат практики над теорією. 
Саме діяльність в ім'я людини є квінтесенцією життя, і лише Людина, яка до кінця віддана цій справі, отримує задоволення й відчуття найвищого щастя, а тому захоплено благає: «О, мить, спинися, - ти прекрасна!»

Зосередимо наш аналіз на одному з найбільш відомих (хрестоматійних) віршів Гете «Erlkönig», що українською мовою перекладається двояко: «Лісовий цар» або «Вільшаний король». До уваги пропонуємо два варіанти перекладу: відомого громадського діяча, видавця, письменника та лінгвіста Б.Д. Грінченка та славнозвісного українського поета радянської пори, академіка та лауреата багатьох найпрестижніших премій М.Т. Рильського. Одним із напрямків багатогранної діяльності Бориса Грінченка була перекладацька творчість. Серед його відомих робіт знаходимо, зокрема, переклади західноєвропейських авторів, насамперед, німецькомовних - Й.В. Гете, Ф. Шиллера, Г. Гауптмана та інших. В перекладі анонсованої балади відчувається досвідчений майстер, який чудово володіє такими поняттями як віршований ритм та віршований розмір, де має місце слушне чергування наголошених та ненаголошених складів. Перекладач дотримується сумірності віршованих стрічок, що віддзеркалює тонічну будову оригіналу, а подекуди й прояви алітерації, що успадкована автором від давньогерманських традицій.

Ставлячись $з$ повагою до високої майстерності перекладача, дозволимо собі, поряд 3 тим, декілька зауважень. Так у другій строфі, перший рядок, дещо зайвим видається поєднання займенників (ти, мій); значно краще, без порушення ритму, звучатиме дієслово у теперішньому часі $($ сховав = ховаєш), трьохскладова будова якого компенсує усунення займенника ㄸ. Схожу конструкцію знаходимо також у наступній третій строфі, а також у восьмій (останній) строфі, де подвійне вживання займенника він не є стилістично виправданим. У четвертій строфі, далеко не безперечним видається третій рядок- Нема там нічого, мій синочку. Цить! - де невірний наголос у словоформі синочку дещо порушує віршований ритм, де певним дисонансом звучить вигук-окрик Цить! і де зовсім недоречним є його застосування по відношенню до тяжко хворої, вмираючої дитини.

Лексико-граматичну неточність спостерігаємо у перекладі третього рядку сьомої (передостанньої) строфи, де слова оригіналу - jetzt faßt er mich an - перекладено - він нас дожене!; хоча дієслово anfassen означає «хапати», що свідчить, що король вже схопив дитину (порівн. 
наш варіант перекладу). Залишимо також поза увагою переклад окремих лексичних одиниць, оскільки вони не завадять повноті викладу та перекладу у цілому. Дозволимо собі лише зауважити, що вживання дієслова нудьгувати (другий рядок останньої строфи) не може бути коректним по відношенню до дитини, яка помирає.

Насамкінець вкажемо (не коментуючи) на помітну еквівалентність варіанту перекладу Б. Грінченка перекладу аналізованої балади, здійсненого значно раніше російським поетом і перекладачем В. А. Жуковським. Аргументуючи, порівняємо, принаймні, варіанти перекладу останньої (восьмої) строфи балади:

\section{В.А. Жуковський}

Ездок оробельй не скачет, летит;

Младенеи тоскует, младенец кричит;

Ездок погоняет, ездок доскакал...

В руках его мертвый младенеи лежал.

Б.Д. Грінченко

Наляканий батько не їде - летить...

А хлопець нудьгує, а хлопець кричить.

Добіг він додому і дивиться він:

В руках уже мертвий лежить його син.

Взірець майстерності у перекладі балади знаходимо у М. Рильського, який дотримується усталених канонів, звертаючи увагу як на віршований розмір, так і на чергування наголошених і ненаголошених складів, що утворюють віршований ритм і зумовлюють силабо-тонічну будову вірша. Кожна стопа, так само як і в оригіналі, складається, зазвичай, із двох складів, послідовність яких визначає його розмір (у даному випадку - ямб).

Поряд $з$ тим переклад М. Рильського залишає деякі (на нашу думку - незначні) питання. Так, перший рядок другої строфи перекладено як «Чому тремтиш ти, синку, щомить?!», хоча більш правильним буде наш варіант перекладу: «Мій сину, чому ти ховаєш лице?» (порівн. оригінал). Перший рядок четвертої строфи «Мій тату, мій тату, яке страшне!» Не зовсім зрозуміло, про яке саме «страшне» йдеться. Не зовсім коректним сприймається переклад передостанньої (сьомої) строфи. Наведемо іï. 
«Мені, хлопче, люба краса твоя!

3 неволі чи волі візьму тебе я!»

«Мій тату, мій тату, він нас догнав!

Ой, як болюче мене він обняв!»

Іменник-звертання «хлопче» відсутній в тексті оригіналу, до того ж ця форма може бути доречною, коли мова йде про підлітка, а в оригіналі маємо справу з дитиною. Незрозумілим є вживання прийменника «з» у наступному рядку:

«3 неволі чи волі...» Нарешті (третій рядок), дієслово anfassen означає «торкатися, хапати», проте перекладач вживає форму «догнав». Остання строфа, на наш погляд, перевантажена займенниками, що, звичайно, не додає перекладу образної виразності й дещо його збіднює.

Наведемо оригінал балади та наш варіант перекладу:

\section{ERLKÖNIG}

Wer reitet so spät durch Nacht und Wind?

Es ist der Vater mit seinem Kind;

Er hat den Knaben wohl in dem Arm,

Er faßt ihn sicher, er hält ihn warm.

„Mein Sohn, was birgst du so bang dein Gesicht? “

„,Siehst Vater, du den Erlkönig nicht?

Den Erlenkönig mit Kron und Schweif? “

„, Mein Sohn, es ist ein Nebelstreif. “

„Du liebes Kind, komm, geh mit mir!

Gar schöne Spiele spiel ich mit dir;

Manch bunte Blumen sind an dem Strand;

Meine Mutter hat manch gülden Gewand. "

„,Mein Vater, mein Vater, und hörest du nicht,

Was Erlenkönig mir leise verspricht?"

„Sei ruhig, bleibe ruhig, mein Kind:

In dürren Blättern säuselt der Wind. “

„, Willst, feiner Knabe, du mit mir gehn?

Meine Töchter sollen dich warten schön; 
Meine Töchter führen den nächtlichen Reihn Und wiegen und tanzen und singen dich ein. “

„, Mein Vater, mein Vater, und siehst du nicht dort Erlkönigs Töchter am düstern Ort? “

„,Mein Sohn, mein Sohn, ich seh es genau:

Es scheinen die alten Weiden so grau. "

„, Ich liebe dich, mich reizt deine schöne Gestalt;

Und bist du nicht willig, so brauch ich Gewalt."

„,Mein Vater, mein Vater, jetzt faßt er mich an!

Erlkönig hat mir ein Leids getan!"

Dem Vater grauset's, er reitet geschwind, Er hält in den Armen das ächzende Kind, Erreicht den Hof mit Mühe und Not;

In seinen Armen das Kind war tot. [2, c. 906]

\section{ВІЛЬШАНИЙ КОРОЛЬ}

Хто скаче так лісом вночі, безупинно, То батько збентежений, разом із сином; До серчя хлопчину свого пригортає, В руках його гріє і міино тримає.

«Мій сину, чому ти ховаєш лище?» «Хіба ти не бачиш? - хлопчина на цее, Вільшаний король у багатім плащі.»«То стелиться, сину, туман у ночі.»

«Хлопчина, мій любий, ходімо зі мною! Ми весело час проведемо з тобою; На березі моря ростуть пишні квіти; В багату одежу матуся одіта.»

«Татусю, татусю, хіба ти не чуєш Того, щуо король мені знов пропонує?» 
«Не бійсь, не хвилюйся, о любе дитя;

У листях посохлих то вітру виття.»

«Чи хочеш, мій хлопчик, зі мною піти?

Там доньки мої, з ними злагодиш ти;

Там доньки ведуть опівнічний танок,

Тебе заколише їх пісень вінок.»

«Татусю, татусю, здається мені:

Я бачу тих доньок в жахливій пітьмі.»

«Мій сину, мій сину, я бачу відверто:

То стали від часу стемнілими верби.»

«Мій любий, спокусливе тіло твоє;

Я сил докладу, бач, вони в мене є.»

«Татусю, тепер він хапає мене,

Нестерпного болю король завдає!»

Наляканий батько ходи додає,

Він міино тримає дитятко своє,

Останнім зусиллям дістався двора;

Дитина, проте, уже мертва була.

\section{4. Феномен перекладу Ф. Шиллера}

Продовжуючи аналіз окремих поезій німецьких класиків, зупинимося стисло на творчості Ф. Шиллера. Відомо, що на церемонії по вшануванню пам'яті великого німецького поета його друг і соратник Гете проголосив [9, с. 25]:

„,Denn er war unser! Mag das stolze Wort

Den lauten Schmerz gewaltig übertönen!

Er mochte sich bei uns im sichern Port

Nach wildem Sturm zum Dauernden gewöhnen.

Indessen schritt sein Geist gewaltig fort

Ins Ewige des Wahren, Guten, Schönen,

Und hinter ihm, in wesenlosem Scheine,

Lag, was uns alle bändigt, das Gemeine. “ 
Тому щзо він був наш! Цих гордих слів акорд

Біль гострий допоможе нам здолати!

I він би зміг у нас знайти безпечний порт,

I, переживши шторм, відпочивати.

Натомість дух його могутній відійшов

У вічність правди, красоти і щзастя,

А поза ним в безмовнім сяйві дальнім

Лишилось, щзо єднає нас, - загальне.

Таке визнання свідчить про особливу роль Шиллера як поета і як особистості у розвитку німецької літератури та німецького суспільства у цілому, а також про його невтомне прагнення до самовдосконалення і боротьбу за честь і гідність людини.

Історико-філософська та світоглядна лірика Шиллера досягла свого апогею, насамперед, у таких баладах поета як «Ідеали» («Die Ideale»), «Ідеал і життя» («Das Ideal und das Leben»), «Прогулянка» («Der Spaziergang») та ін. Так, зокрема, в «Ідеалах» йдеться про перехід від юності до життєвої зрілості, а також про неминучість відходу від щасливої пори. Певний розпач автора змінюється проте на впевненість, що невтомна праця, творча діяльність допоможуть людині подолати життєві труднощі.

Досліджуючи поетичну творчість Шиллера, а також становлення й розвиток балади як окремого жанру, стикаємося із поняттям «Рік балади» («Balladenjahr»), датованим 1797 роком. Саме тоді 3’являються кращі балади поета: «Пірнач» («Der Taucher»), «Рукавичка» («Der Handschuh»), «Івикові журавлі» («Die Kraniche des Ibykus») та ін.

У своїх баладах Шиллер виносить на розгляд читача проблеми взаємин суспільства і окремої людини. Герої його балад потрапляють, зазвичай, у екстраординарні ситуації, що вимагають від них прийняття миттєвих і рішучих дій і експлікують їх фізичні і моральні якості. У такий спосіб балади реалізують свої ідеологічні й світоглядні функції й слугують вирішенню проблем суспільства й формуванню відповідних переконань і лінії поведінки. Так, у баладі «Пірнач» [9, с. 57-61] ми констатуємо морально-етичні розбіжності у нормах поведінки й прийнятті рішень $з$ боку нелюдяного короля й хороброго але недосвідченого юнака, якого монарх прирікає на смертельну небезпеку. Повіривши в обіцянку короля щодо можливих благ і особистого щастя, юнак, всупереч своїм 
переконанням, вдруге пірнає в безодню, звідки він вже не повертається. Порівняємо фрагмент балади з авторським перекладом:

Da ergreift's ihm die Seele mit Himmelsgewalt,

Und es blitzt aus den Augen ihm kühn,

Und er siehet erröten die schöne Gestalt

Und sieht sie erbleichen und sinken hin-

Da treibt's ihn, den köstlichen Preis zu erwerben,

Und stürzt hinunter auf Leben und Sterben.

Wohl hört man die Brandung, wohl kehrt sie zurück,

Sie verkündigt der donnernde Schall-

Da bückt sich's hinunter mit liebendem Blick:

Es kommen, es kommen die Wasser all,

Sie rauschen herauf, sie rauschen nieder,

Den Jüngling bringt keines wieder.

За душу бере його сила небесна,

I полум'ям погляд відважний палає,

Він бачить: здригається постать чудесна,

І голову дівчина зблідла схиляє;

До дї иеей приз юнака спонукає,

Він в прірву бурхливу рімуче стрибає.

Прибій то навалить, то знову відскоче,

І гуркіт слугує відгомоном силі, -

I в прірву вдивляються люблячі очі,

На берег збігають високії хвилі;

За першою - друга ї̈ доганяє,

Та жодна хлопчину назад не вертає.

Герой балади «Рукавичка», хоробрий рицар Делоргес, виконуючи примхи вельможної пані, дістає рукавичку, яку вона випускає за межі альтана, де чатують хижі тварини. Виражаючи своє ставлення до дійства, Делоргес «гнівно жбурля рукавичку в лице» Кунігунди. Таким чином, герой не погоджується на потурання вельможі і зберігає свою гідність, спростовуючи усталену думку про необмеженість дій можновладців. 
Серед небагатьох відомих перекладів цієї балади привертає до себе увагу доробка поета й перекладача Михайла Ореста [1, с. 872]. Значне місце у його творчості посідають також переклади творів Р. Рільке (R. M. Rilke), Г. Гофмансталь (H. von Hofmannsthal), а також поезії німецького класика Ф. Шиллера (F. Schiller). Відповідно до мети нашої роботи розглянемо баладу більш детально. Для наочності і вичерпності аналізу наведемо оригінал і варіант перекладу М. Ореста повністю.

\section{РУКАВИЧКА}

Ждучи на грища $і$ забави,

В звіринці свойм величаво

Король Франиіск сидів;

Тіснились вельможі при троні А кругом, на високім балконі

Дам барвистий вінок процвів.

Король дав знак рукою -

I з трат сторожкою стопою

Виходить лев;

Але не лунає рев:

Пустелі друг

Зором німим обводить круг

Арени -

I випростав з позіхом лапи,

І гривою стряс густою,

І ліг самотою.

I знову владар маше рукою -

На знак иарський

Тигр жаський

3 клітки рине тісної

Скоком потужним;

Лева він бачить і виє,

Напружує шию,

Кола страшні вибиває хвостом

І лиже рот язиком;

I кроком несміло-пружним

Лева обходить він

I, волі невольний син,

Повнить арену риком

Хрипким і диким.-

\section{DER HANDSCHUH}

Vor seinem Löwengarten,

Das Kampfspiel zu erwarten,

Saß König Franz,

Und um ihn die Großen der Krone,

Und rings auf hohem Balkone

Die Damen in schönem Kranz.

Und wie er winkt mit dem Finger,

Auf tut sich der weite Zwinger,

Und hinein mit bedächtigem Schritt

Ein Löwe tritt

Und sieht sich stumm

Rings um,

Mit langem Gähnen,

Und schüttelt die Mähnen

Und streckt die Glieder

Und legt sich nieder.

Und der König winkt wieder,

Da öffnet sich behend

Ein zweites Tor,

Daraus rennt

Mit wildem Sprunge

Ein Tiger hervor.

Wie der den Löwen erschaut,

Brüllt er laut,

Schlägt mit dem Schweif

Einen furchtbaren Reif,

Und recket die Zunge,

Und im Kreise scheu

Umgeht er den Leu

Grimmig schnurrend, 
Погас його рев луною,

I осторонь хижий ліг.

I знову владар маше рукою I з во дверей вивертає їх:

Двох леопардів прудких;

В буянні мужнього палу

На тигра вони напали;

Той лапою б’є їх тяжкою,

І вже підводиться лев;

Його могутній рев

Прогримів - і став спокій;

I, не давши волі злобі рвачкій,

Люті лягли по короткім бою.

Нової жде битви вельможне гроно.

I раптом упала з балкона

Рукавичка красної дами

Між хижаками.

І мовить лицарю юна

Кунігунда, глузлива красуня:

«Щодня, щогодини, лицарю мій,

Присягаєтесь ви в любові своій -

Принести рукавичку прошу вас!»

I лицар Делорж поспішає і враз

Збігає наниз безстрашно,

I кроком твердим

Ступає між звіром тим,

I бере рукавичку відважно.

I, повні подиву й жаху німого,

Лицарі й дами глядять на нього,

А він, спокійний, назад іде -

I гомін безмежний навколо росте

На честь його перемоги.

Кунігунда героя очима вітає -

Той погляд щастя йому обіияе -

Але, зійшовши під крики бучні,

Він рукавичку в лице ій кинув:

«Подяки, дамо, не треба мені»-

Сказав і ї̈ покинув.
Drauf streckt er sich murrend

Zur Seite nieder.

Und der König winkt wieder,

Da speit das doppelt geöffnete Haus

Zwei Leoparden auf einmal aus,

Die stürzen mit mutiger Kampfbegier

Auf das Tigertier;

Das packt sie mit seinen grimmigen Tatzen,

Und der Leu mit Gebrüll

Richtet sich auf - da wird's still;

Und herum im Kreis,

Von Mordsucht hei $\beta$,

Lagern sich die greulichen Katzen.

Da fällt von des Altans Rand

Ein Handschuh von schöner Hand

Zwischen den Tiger und den Leun

Mitten hinein.

Undzu Ritter Delorges spottenderweis',

Wendet sich Fräulein Kunigund':

«Herr Ritter, ist Eure Lieb'so heiß,

Wie Ihr mir's schwört zu jeder Stund,

Ei, so hebt mir den Handschuh auf!»

Und der Ritter in schnellem Lauf

Steigt hinab in den furchtbarn Zwinger

Mit festem Schritte,

Und aus der Ungeheuer Mitte

Nimmt er den Handschuh mit keckem Finger.

Und mit Erstaunen und mit Grauen

Sehen's die Ritter und Edelfrauen,

Und gelassen bringt

er den Handschuh zurück.

Da schallt ihm sein Lob aus jedem Munde, Aber mit zärtlichem Liebesblick Er verheißt ihm sein nahes Glück Empfängt ihn Fräulein Kunigunde.

Und er wirft ihr den Handschuh ins Gesicht:

«Den Dank, Dame, begehr ich nicht!» Und verläßt sie zur selben Stunde. 
Уже побіжний аналіз перекладу переконує нас в тому, що перекладач добре обізнаний з особливостями віршування, він відчуває особливість жанру балади. Єднання людини з природою, відносини окремої людини і суспільства, морально-етичні норми людей, що слугують невід'ємною складовою великого Шиллера, знаходять відгомін у душі й слові перекладача. Поряд з тим, дозволимо собі окремі зауваження.

Автор перекладу далеко не завжди дотримується віршованого розміру та ритму. Не зовсім виправданим є варіювання таких розмірів як ямб, хорей, дактиль та ін. Перекладач має, на нашу думку, право на це, хоча будь-які відступи від форми і змісту, недотримання єдності всіх факторів не забезпечують еквівалентність та адекватність перекладу. Зауваження стосовно розміру (відповідно до строфи): строфа I, рядки 3 і 6; строфа II, - розмір практично розмитий (перелік може бути продовжений).

Висловимо окремо також зауваження лексико-стилістичного характеру. Так, дещо невдалим здається поєднання рядків: «Виходить лев / Але не лунає рев» (II строфа). Неістотно сприймаються лексичні поєднання: «Зором німим обводить круг / I ліг самотою». Не зовсім зрозумілим є поєднання перекладачем третьої і четвертої строфи, що ще більше віддаляє переклад від оригіналу, вміщуючи в собі до того ж не зовсім коректні й адекватні варіанти:

- Лева він бачить і виє;

- I, волі невольний син;

- Погас його рев луною. (це все про тигра - ?)

Вкажемо ще на окремі лексико-семантичні хиби:

- В буянні мужнього палу (про леопардів);

- I, не давши волі злобі рвачкій,

Люті лягли по короткім бою (вільний переклад, неістотне поєднання лексичних одиниць).

Для порівняння наведемо наш варіант перекладу балади «Рукавичка»

\section{РУКАВИЧКА}

Перед свойм звіринцем,

Звичайно, - не одинием,

Там Франи-король сидів. 
3 ним дами на балконі

Й служителі корони, -

Видовищ він хотів.

Лиш пальцем він помахає, -

Хтось браму відчиняє,

I звідти, гамуючи рев,

Виходить лев,

I позира некволо

Довкола,

Протяжно зіває,

I гривой хитає;

Простягає лапи

I лягає на піл.

Король знову махає, -

Мерщій відчиняе

Слуга другу браму,

I, вихор неначе,

Звідтіль тигр скаче

I мчить на ринг прямо.

На лева, щзо ліг відпочить,

Вголос ричить;

Б'є землю хвостом,

Здійма пил стовпом

Й висуває язик;

Лякливо ступає

I лева минає,

Рикаючи люто;

Затім ледве чутно

На землю лягає.

Король знову махає,

Подвійні ворота слуга відчиняє

I двох леопардів на ринг випускає. 
Ті стрімко несуться з жагою до бою На тигра обоє;

Та відсіч дають його лапи обидві,

Сердито тут голову лев піднімає, I враз все стихає,

I в коло, відверто

Пильнуючи жертву,

Коти розляглися огидні.

I тут випускає прекрасная панна

Свою рукавичку за межі альтана,

Та падає вниз, де чатують тварини, -

Якраз поміж ними.

Тоді Кунігунда, чарівная діва,

Делоргесу, рицарю, мовить глузливо:

"Чи справжнє, о рицарю, Ваше кохання,

В якім ви клянетесь від самого рання;

Якщзо то не звук і не фрази одні, -

Мерщій підніміть рукавичку мені!»

I рицар у відповідь діє рішуче:

Спускається швидко на поле двобою

І рухом єдиним,

Де хижі тварини,

Бере рукавичку сміливо рукою.

Завмерли від подиву й жаху в чеканні

Поважнії рицарі, важнії панні, А він незворушно несе рукавичку.

Йому звідусіль виголошують славу, А погляд чарівний до того ж віщуе I зустріч щзасливу йому пророкує, Приймає його Кунігунда по праву. Ïй гнівно жбурля рукавичку в лище: «Подяка мені не потрібна за иче!» I швидко виходить, подалі від сраму. 


\section{5. Дослідження мотивів поезії Г. Гейне}

Особливих слів та найвищої оцінки заслуговує ще один геній німецької поезії Г. Гейне (Heinrich Неine). Його твори пронизані мотивами патріотизму і ностальгії за далекою Вітчизною, адже більшу частину свого життя поет провів на чужині. Мотивами ліризму та туги пронизана, наприклад поезія «Ein Fichtenbaum» [4, с. 70]. Простота та незвичайна образність твору Гейне постійно приковувала увагу перекладачів. У російськомовному варіанті найбільш відомі переклади М. Лермонтова та Ф. Тютчева. Розуміючи велич творчої обдарованості автора оригіналу, перекладачі проте не завжди знаходять адекватні способи втілення задуму поета. Так, ліризм і художня досконалість перекладу цих поетів блискуче передають нудьгу самітництва, проте там відсутній трагізм нерозділеної любові, а відмінність граматичного роду (кедр-пальма) у Гейне не стало індикатором перекладу у Лермонтова та інших перекладачів (сосна-пальма).

Неодноразово до шедевру Гейне зверталися українські перекладачі I. Франко, В. Кобилянський, Л. Первомайський та ін. На жаль жодному 3 них не вдалося досягнути повної адекватності перекладу. Наведемо, на наш погляд, найбільш вдалий переклад Л. Первомайського:

Самотній кедр на стромині

В північній стоїть стороні,

I, кригою й снігом укритий,

Дрімає і мріє вві сні.

I бачить він сон про пальму,

Що десь у південній землі

Сумуе в німій самотині

На спаленій сонцем скалі.

На завершення наведемо наш український варіант перекладу поезії великого поета.

Стоїть одиноко на півночі сивім,

На голій вершині сосна.

І снігом іністим, мов саваном білим,

Покрита, і мріє вона;

Що десь на осонні, на мисі спекотнім,

У краї, де соние встає, 
Стоїть кипарис, мовчазний і самотній, І звістку він їй подає...

На завершення виносимо на розсуд читача наш переклад відомої поезії Г. Гейне «Лорелея». Будемо вдячні за можливі зауваження та критику.

\section{LORELEI}

Ich weiß nicht, was soll es bedeuten Daß ich so traurig bin;

Ein Märchen aus alten Zeiten,

Das kommt mir nicht aus dem Sinn.

Die Luft ist kühl, und es dunkelt,

Und ruhig fließt der Rhein;

Der Gipfel des Berges funkelt

Im Abendsonnenschein.

Die schönste Jungfrau sitzet

Dort oben wunderbar,

Ihr goldnes Geschmeide blitzet,

Sie kämmt ihr goldenes Haar.

Sie kämmt es mit goldenem Kamme,

Und singt ein Lied dabei;

Das hat eine wundersame,

Gewaltige Melodei.

Den Schiffer in kleinen Schiffe

Ergreift es mit wildem Weh;

Er schaut nicht die Felsenriffe,

Er schaut nur hinauf in die Höh'.

Ich glaube, die Wellen verschlingen Am Ende Schiffer und Kahn;

Und das hat mit ihrem Singen

Die Lorelei getan

\section{ЛОРЕЛЕЯ}

Не знаю, що сталось зі мною, В душі мойй смуток і сум; Та казка - порушник покою, Володар усіх мойх дум.

Смеркається, свіже повітря, I Рейн посивілий тече;

На горах виблискують вістря I сонечко вже не пече.

Сидить там прекрасная діва, Iз злата намисто плете, Розчесує втім неквапливо Волосся своє золоте.

Гребінчик у діви із злата, I пісню чудову співа; Мелодії сила крилата, Від неї усе ожива.

Мелодія шкіпера кличе, I серие від неї щемить; На діву - юначьке обличчя,

На рифи корабель летить Я знаю, що хвилі поглинуть Корабель і шкіпера вкрай; І все ие свойм чудо-співом Вчинила ота Лореляй. 


\section{6. Висновки}

Розуміння тексту перекладачем передбачає знання ним історії суспільства, інституцій, соціальних умов, релігійних переконань, культурно й ситуативно зумовлених зразків мовленнєвої діяльності та поведінки «вихідної культури», а також обізнаність у синтаксисі та семантиці «вихідного тексту» та їх структурах. Кожен переклад створює динамічний зв'язок і являється міжкультурним перенесенням тексту в тій мірі, наскільки він враховує культурно-специфічне зіставлення мови, ситуації та об’єкту, про який іде мова. 3 позицій герменевтики і під кутом зору перекладу розбіжність культур означає відмінність між «вихідною культурою» і тим самим - культурою «вихідної мови» та «цільовою культурою», а тим самим - культурою «цільової мови».

Підсумовуючи наші доробки та доробки відомих перекладачів маємо змогу ще раз переконатися в тому, що мистецтво перекладу є одним із найбільших надбань і досягнень філології. Навіть найдосконаліші варіанти перекладів не дають абсолютно адекватної картини дійсності, про яку йдеться в оригіналі. Перекладач певною мірою стоїть над автором, адже він, маючи найдосконаліший рівень підготовки у рідній мові поринає у інший світ - світ інших образів, реалій, лексики, історії і культури, і на кінець, духу народу. Час народжує все нових дослідників і перекладачів поезії, тому що будь-який переклад - це мистецтво. А мистецтво - вічне.

Отже, студіюючи переклад як міжмовний процес комунікації, аналізуємо, які мовні операції слід виконати, для того, щоб забезпечити інтеграцію вихідного та цільового текстів і разом з тим усунути їх інтерлінгвістичні структурні відмінності на понятійному та стилістичному рівнях.

\section{Список літератури:}

1. Encyclopedia of Ukraine in 5 Volume. Volume III. University of Toronto Press Incorporated, 1993. $872 \mathrm{p}$.

2. Goethe. Poetische Werke in drei Bänden. Aufbau - Verlag, Bd. 1, 1970. $906 \mathrm{~s}$.

3. Goethe. Poetische Werke in drei Bänden. Aufbau - Verlag, Bd. 3, 1970. 912 s.

4. Heine Heinrich Im Anfang war die Nachtigall: Aus Lyrik und Prosa. Verlag Neues Leben. Berlin, 1966. 447 s.

5. Kade, Otto. Zufall und Gesetzmässigkeit in der Übersetzung. Leipzig : VEB Verlag Enzyklopädie, 1968.

6. Koller, Werner. Einführung in die Übersetzungswissenschaft. Heidelberg / Wiesbaden : Quelle \& Meyer, 1992. 
7. Reiss, Katharina. Vermeer, Hans. Grundlegung einer allgemeinen Translationstheorie. Tübingen, 1991.

8. Reiss, Katharina. Übersetzungstheorie und Praxis der Übersetzungskritik. In: Übersetzungswissenschaft und Fremdsprachenunterricht. Goethe-Institut München, 1989.

9. Schiller. Ein Lesebuch für unsere Zeit. Aufbau-Verlag, Berlin und Weimar, 1976. 450 S. S.LIV-LXII.

10. Vermeer, Hans. Übersetzen als interkultureller Transfer. In: Stolze, Radegundis. Übersetzungstheorien. Eine Einführung. 5. Auflage. Gunter Narr Verlag Tübingen, 2008.

11. Vinay, Jean-Paul. Darbeinet, Jean. Comparative Stylistics of French and English: A Methodology for Translation. Amsterdam. Philadelphia, 1995.

12. Wilss, Wolfram. Übersetzungswissenschaft. Probleme und Methoden. Stuttgart: Klett, 1977.

13. И. В. Гёте. Фауст. Лирика. Москва: «Художественная литература», 1986. $767 \mathrm{c}$.

\section{References:}

1. Encyclopedia of Ukraine in 5 Volume. Volume III. University of Toronto Press Incorporated, 1993. $872 \mathrm{p}$.

2. Goethe. Poetische Werke in drei Bänden. Aufbau - Verlag, Bd. 1, 1970. 906 s.

3. Goethe. Poetische Werke in drei Bänden. Aufbau - Verlag, Bd. 3, 1970. 912 s.

4. Heine Heinrich Im Anfang war die Nachtigall: Aus Lyrik und Prosa. Verlag Neues Leben. Berlin, 1966. 447 s.

5. Kade, Otto. Zufall und Gesetzmässigkeit in der Übersetzung. Leipzig: VEB Verlag Enzyklopädie, 1968.

6. Koller, Werner. Einführung in die Übersetzungswissenschaft. Heidelberg / Wiesbaden: Quelle \& Meyer, 1992.

7. Reiss, Katharina. Vermeer, Hans. Grundlegung einer allgemeinen Translationstheorie. Tübingen, 1991.

8. Reiss, Katharina. Übersetzungstheorie und Praxis der Übersetzungskritik. In: Übersetzungswissenschaft und Fremdsprachenunterricht. Goethe-Institut München, 1989.

9. Schiller. Ein Lesebuch für unsere Zeit. Aufbau-Verlag, Berlin und Weimar, 1976. 450 S. S.LIV-LXII.

10. Vermeer, Hans. Übersetzen als interkultureller Transfer. In: Stolze, Radegundis. Übersetzungstheorien. Eine Einführung. 5. Auflage. Gunter Narr Verlag Tübingen, 2008.

11. Vinay, Jean-Paul. Darbeinet, Jean. Comparative Stylistics of French and English: A Methodology for Translation. Amsterdam. Philadelphia, 1995.

12. Wilss, Wolfram. Übersetzungswissenschaft. Probleme und Methoden. Stuttgart: Klett, 1977.

13. I. V. Gete. Faust. Lirika. Moskva: «Khudozhestvennaya literatura», 1986.767 s. 